medRxiv preprint doi: https://doi.org/10.1101/2020.11.23.20236703; this version posted November 24, 2020. The copyright holder for this preprint (which was not certified by peer review) is the author/funder, who has granted medRxiv a license to display the preprint in perpetuity.

It is made available under a CC-BY-NC-ND 4.0 International license .

\title{
Evidence of the effectiveness of travel-related measures during the early phase of the COVID- 19 pandemic: a rapid systematic review
}

Tsi Lok Ho, Faculty of Medicine, University of Hong Kong, China

Zhihan Liu, MPH, School of Public Health, University of Hong Kong, China

Summer Marion, PhD, School of Public Policy, University of Maryland, USA

Julianne Piper, MIA, Faculty of Health Sciences, Simon Fraser University, Canada

Catherine Z. Worsnop, PhD, School of Public Policy, University of Maryland, USA

Kelley Lee, PhD, Faculty of Health Sciences, Simon Fraser University, Canada

\section{Abstract}

Objective To review evidence of the effectiveness of travel measures implemented during the early stages of the COVID-19 pandemic in order to recommend change on how evidence is incorporated in the International Health Regulations (2005) (IHR).

Design We used an abbreviated preferred reporting items for systematic reviews and metaanalysis protocol (PRISMA-P) and a search strategy aimed to identify studies that investigated the effectiveness of travel-related measures (advice, entry and exit screening, medical examination or vaccination requirements, isolation or quarantine, the refusal of entry, and entry restrictions), pre-printed or published by June 1, 2020.

Results We identified 29 studies, of which 26 were modelled (vs. observational). Thirteen studies investigated international measures while 17 investigated domestic measures (one investigated both), including suspended transportation (24 studies), border restrictions (21), and screening (5). There was a high level of agreement that the adoption of travel measures led to important changes in the dynamics of the early phases of the COVID-19 pandemic. However, most of the identified studies investigated the initial export of cases out of Wuhan, 38 which was found to be highly effective, but few studies investigated the effectiveness of 39 measures implemented in other contexts. Early implementation was identified as a 40 determinant of effectiveness. Most studies of international travel measures failed to account

\footnotetext{
${ }^{a}$ Corresponding author: 7 Sassoon Road, Pokfulam, Hong Kong SAR, China; kgrepin@hku.hk
} 
medRxiv preprint doi: https://doi.org/10.1101/2020.11.23.20236703; this version posted November 24, 2020. The copyright holder for this preprint (which was not certified by peer review) is the author/funder, who has granted medRxiv a license to display the preprint in perpetuity.

It is made available under a CC-BY-NC-ND 4.0 International license .

1 for domestic travel measures, and thus likely led to biased estimates. Poor data and other

2 factors contributed to the low quality of the studies identified.

3

Conclusion Travel measures, especially those implemented in Wuhan, played a key role in shaping the early transmission dynamics of the COVID-19 pandemic, however, the effectiveness of these measures was short-lived. There is an urgent need to address important evidence gaps, but also a need to review the way in which evidence is incorporated in the IHR in the early phases of a novel infectious disease outbreak.

\section{What is already known on this subject?}

- Previous reviews of the evidence from outbreaks of influenza and other infectious disease have generally found that there is limited evidence that travel-measures are effective at containing outbreaks.

- However, it is unclear if the lessons from other infectious disease outbreaks would be relevant in the context of COVID-19.

- Based on evidence at the time, WHO did not recommend any travel restrictions when it declared COVID-19 a Public Health Emergency of International Concern.

\section{What does this study add?}

- This study rapidly reviews the evidence on the effectiveness of travel measures implemented in the early phase of the pandemic on epidemiological countries.

- The study investigated both international and domestic travel measures and a wide range of travel measures.

- The study finds that the domestic travel measures implemented in Wuhan were effective at reducing the importation of cases internationally and within China. The study also finds that travel measures are more effective when implemented earlier in the outbreak.

- The findings generate recommendations on how to incorporate evidence into the International Health Regulations and highlights important research gaps that remain.

\section{How might this affect future outbreaks?}

- The findings of this study suggest the need to decouple recommendations of travel measures from the declaration of a public health emergency of international concern.

- Highlights the need to evaluate the potential effectiveness of travel measures for each outbreak, and not just assume effectiveness based on past outbreak scnearios. 
medRxiv preprint doi: https://doi.org/10.1101/2020.11.23.20236703; this version posted November 24, 2020. The copyright holder for this preprint (which was not certified by peer review) is the author/funder, who has granted medRxiv a license to display the preprint in perpetuity.

It is made available under a CC-BY-NC-ND 4.0 International license .

\section{Introduction}

2 On January 31, 2020, the World Health Organization (WHO) declared the outbreak of SARS-

3 CoV-2 a Public Health Emergency of International Concern (PHEIC). Based on information

4 available at the time, the International Health Regulations 2005 (IHR) Emergency Committee

5 explicitly did not recommend "any travel or trade restriction". ${ }^{1}$ The IHR state that State Parties

6 should avoid unnecessary interference with international traffic in the adoption of measures

7 and that the measures should not be "more restrictive of international traffic and not more

8 invasive or intrusive to persons than reasonably available alternatives that would achieve the

9 appropriate level of health protection" (Article 43). Moreover, measures adopted should be

10 based on "scientific principles," evidence and/or WHO guidance.

12 As early as December 31, 2019, the same day that China Centre for Disease Control first notified

13 WHO of a cluster of atypical pneumonia cases in Wuhan, some authorities (including Taiwan,

14 Russia, and Macau) began to impose targeted travel-related measures, mainly airport screening

15 of travellers from Wuhan. ${ }^{2}$ Within weeks, additional locations also restricted flights to or

16 suspended entry from Wuhan, including Mongolia, Australia, and North Korea. On January 23, a

17 cordon sanitaire was drawn around Wuhan, effectively suspending all international and

18 domestic travel in and out of the city. ${ }^{3}$ A day later, the measures were extended to all of Hubei

19 province. By March 2020, despite WHO's recommendations, virtually all IHR (2005) States

20 Parties had implemented some form of cross-border travel-related measure in response to the

21 COVID-19 pandemic. ${ }^{4}$ This is, by far, the largest number of countries adopting such measures

22 during a PHEIC: only about a quarter of countries had imposed such measures during the 2009 
medRxiv preprint doi: https://doi.org/10.1101/2020.11.23.20236703; this version posted November 24, 2020. The copyright holder for this preprint (which was not certified by peer review) is the author/funder, who has granted medRxiv a license to display the preprint in perpetuity.

It is made available under a CC-BY-NC-ND 4.0 International license .

1 H1N1 pandemic and the 2014 Ebola outbreak in West Africa. ${ }^{5-7}$ It is estimated that there was a

$265 \%$ drop in international travel in the first half of 2020 as a result of the COVID-19 pandemic. ${ }^{8}$

4 The near universal adoption of travel-related measures, especially in light of the potentially

5 large economic and social consequences, raises questions as to whether such measures can be,

6 and have been, effective at reducing international transmission of the virus during the

7 pandemic. Previous studies have suggested that certain travel-related measures have only

8 limited, or at best modest, effectiveness in containing outbreaks of influenza. A systematic

9 review of the effectiveness of international travel measures (screening, travel restrictions, and

10 border closures) to control pandemic influenza identified only 15 studies and found that

11 measures implemented early could delay local transmission by a few days or weeks, slow

12 international spread, and delay the epidemic peak in isolated locations by reducing the number

13 of seeding events. ${ }^{9}$ The review did not identify any evidence that screening methods were

14 effective but it did find that border closures had been effective in preventing virus introduction

15 to small island states during the 1918 influenza pandemic. However, the authors also concluded

16 that the overall evidence base on which they drew their conclusions was small and of low

17 quality.

19 A related but larger review of a broader range of measures, including travel advice, screening,

20 internal travel restrictions, and border closures, for both epidemic and pandemic influenza, also

21 found that travel restrictions could delay the arrival and spread of epidemics and that select

22 isolated locations may benefit from border closures. Once again, however, the overall size of 
medRxiv preprint doi: https://doi.org/10.1101/2020.11.23.20236703; this version posted November 24, 2020. The copyright holder for this preprint (which was not certified by peer review) is the author/funder, who has granted medRxiv a license to display the preprint in perpetuity.

It is made available under a CC-BY-NC-ND 4.0 International license .

1 the effects was relatively small and the quality of evidence was found to be very low. ${ }^{10}$ Another

2 review of both international and domestic travel restrictions concluded that such measures

3 could delay, but not contain, dissemination of both pandemic and seasonal influenza after it

4 emerged. $^{11}$ Based on the 23 studies identified, the review concluded that internal and

5 international border restrictions could delay the spread of an outbreak by one week and two

6 months, respectively, and that such restrictions could delay the spread and peak of epidemics

7 from between a few days to up to four months. However, the timing of the introduction of such

8 measures was key - the extent of the delay of spread was greatly reduced when restrictions

9 were imposed more than six weeks after the onset of an epidemic.

10

11 Beyond influenza, evidence from other infectious disease outbreaks is more limited. A

12 modelling study of travel restrictions implemented during the West African Ebola outbreak

13 estimated that they may have delayed further international transmission by a few weeks for

14 some countries. ${ }^{12}$ Given the low proportion of all international travellers originating in Ebola-

15 affected countries at that time, another study suggested that exit screening measures in

16 affected countries were likely to be more effective at reducing onward international

17 transmission than travel restrictions, ${ }^{13}$ a finding that was supported by another similar study. ${ }^{14}$

18 The travel advisories issued by WHO during the 2003 SARS outbreak, which led to substantial

19 declines in international travel to Hong Kong and Mainland China, were estimated to have

20 delayed the export of cases by only a few days. ${ }^{15}$ Importantly, other studies have suggested

21 that travel measures during outbreaks can be counter-productive by preventing countries from

22 launching effective epidemic responses, ${ }^{16}$ undermining the detection of cases, and causing 
medRxiv preprint doi: https://doi.org/10.1101/2020.11.23.20236703; this version posted November 24, 2020. The copyright holder for this preprint (which was not certified by peer review) is the author/funder, who has granted medRxiv a license to display the preprint in perpetuity.

It is made available under a CC-BY-NC-ND 4.0 International license .

1 widespread economic effects on the travel industry itself. ${ }^{17}$ Since the onset of the pandemic, it

2 has become clear that the clinical features of COVID-19 make it more challenging than previous

3 infectious diseases to detect and contain, ${ }^{18}$ raising questions about whether evidence of

4 effectiveness from previous studies is even relevant for COVID-19. ${ }^{19}$

6 The goal of this paper is to review evidence of the effectiveness of travel-related measures

7 implemented during the early stages of the COVID-19 pandemic, a time of many unknowns

8 regarding the clinical and epidemiological features of the novel coronavirus. Since the

9 emergence of COVID-19, dozens of studies have been published or made available that

10 evaluate the effectiveness of travel-related measures in the context of the pandemic. A recent

11 Cochrane review of the literature on the effectiveness of international travel-related measures

12 to contain COVID-19, severe acute respiratory syndrome (SARS), and Middle-East respiratory

13 syndrome (MERS) identified 36 unique studies, of which only 25 were specific to COVID-19. The

14 review concluded that cross-border travel measures may limit the spread of disease across

15 national borders, specifically in terms of reducing the number of imported cases and delaying

16 or reducing epidemic development, although it found that the certainty of the reviewed

17 evidence was low to very low. Importantly, it did not consider travel-related measures adopted

18 within China at the outset of the pandemic or studies that evaluate interventions implemented

19 in combination. Given the widespread adoption of travel restrictions, and the likely enormous

20 economic and social consequences resulting from them, a fuller understanding of the

21 effectiveness of all of the measures adopted during the early phase of the outbreak is 
medRxiv preprint doi: https://doi.org/10.1101/2020.11.23.20236703; this version posted November 24, 2020. The copyright holder for this preprint (which was not certified by peer review) is the author/funder, who has granted medRxiv a license to display the preprint in perpetuity.

It is made available under a CC-BY-NC-ND 4.0 International license .

1 warranted. While the question of whether the adoption of these measures is compliant with

2 the IHR has received attention in the literature, ${ }^{20,21}$ it is beyond the scope of this paper.

4 Methods

5 To conduct this review, we adopted an abbreviated version of the preferred reporting items for

6 systematic reviews and meta-analysis protocol (PRISMA-P) using the 17-point checklist. ${ }^{22}$ The $^{2}$

7 rationale for the study was the widespread adoption of travel-measures despite consensus view

8 at the time that such measures were largely ineffective, and in order to strengthen the

9 application of the IHR during this and future pandemics. The objectives were to rapidly review

10 evidence of the effectiveness of the full range of travel-measures adopted during the early

11 stage of the COVID-19 pandemic form both published and unpublished studies. We further

12 elaborate on other methods of the study below.

\section{$14 \quad 2.1$ Search Strategy}

15 Our search strategy was designed to be as inclusive as possible of all studies (as of June 1, 2020)

16 that provide new evidence of the effectiveness of any travel-related measure adopted during

17 the early phase of the COVID-19 pandemic. According to the IHR, travel-related measures

18 include travel advice, entry and exit screening of travellers, medical examination or vaccination

19 requirements for travellers, isolation or quarantine of suspected or affected persons, the

20 refusal of entry of travellers, and restrictions on travellers from affected areas. ${ }^{1}$ While only

21 those measures that are applied by State Parties at the level of an international border are

22 covered by the IHR, many of these measures have also been applied to domestic travellers (e.g. 
medRxiv preprint doi: https://doi.org/10.1101/2020.11.23.20236703; this version posted November 24, 2020. The copyright holder for this preprint (which was not certified by peer review) is the author/funder, who has granted medRxiv a license to display the preprint in perpetuity.

It is made available under a CC-BY-NC-ND 4.0 International license .

1 at the level of inter-provincial or inter-state borders). Private companies, such as airlines and

2 cruise ships, have also implemented travel measures, which, while also not subject to the IHR,

3 further restricted travel during this pandemic. We did not restrict the search to specific

4 outcomes (e.g. epidemiological or otherwise), or any specific methodological approach, or any

5 specific geography. We only identified one study that looked at non-epidemiological

6 outcomes, ${ }^{23}$ so while we include it in our description of the search and screening strategies, we

7 exclude it from our main analysis below.

9 Given the rapidly evolving nature of the outbreak, as well as the rapidly expanding published

10 literature on COVID-19, our search strategy targeted both pre-print and published articles, with

11 the strategies to identify each differing slightly. Keywords were identified based on both

12 inductive iterative testing of potential keywords, as well as deductively through papers

13 identified through other channels. Search terms were then refined to minimize overlap and to

14 maximize the number of studies that could be identified. While we did not impose a language

15 restriction, we did not specifically search in non-English sources.

17 For pre-print papers, we searched the BioRxiv and MedRxiv servers, which offer limited search

18 functionality, using the following keywords in the title field: travel*, flight*, airline*, border*,

19 airport*, passenger or air traffic. We restricted the sample to papers that also included at least

20 one COVID-19 keyword, either related to the virus itself (e.g. coronavirus, corona virus,

21 coronavirinae, coronaviridae, betacoronavirus, covid19, covid 19, covid-19, nCoV, CoV 2, CoV2,

22 sarscov2, 2019nCoV, novel CoV, OR Wuhan virus), the location of the early outbreak (e.g. 
medRxiv preprint doi: https://doi.org/10.1101/2020.11.23.20236703; this version posted November 24, 2020. The copyright holder for this preprint (which was not certified by peer review) is the author/funder, who has granted medRxiv a license to display the preprint in perpetuity.

It is made available under a CC-BY-NC-ND 4.0 International license .

1 Wuhan, Hubei or Hunan) or less specific but widely used terms (severe acute respiratory OR

2 pneumonia AND outbreak). We used the same travel-related keywords to search the WHO's

3 COVID-19 global research database but did not impose a COVID-19 search term as theoretically

4 all articles in this database were on this topic. ${ }^{b}$

6 For published papers, we searched PubMed with the following search strategy: studies must

7 include at least one COVID-19 keyword mentioned above or one of the location-specific terms

8 mentioned above combined with either ("severe acute respiratory" OR pneumonia AND

9 outbreak) or one of the following MESH terms (Coronavirus, Coronavirus Infections, or

10 Betacoronavirus) or the Supplementary Concept (COVID-19 or severe acute respiratory

11 syndrome coronavirus 2). All studies must in addition include at least one travel-related

12 measure term in the title or abstract (e.g. screening, travel advice, travel advisory, cordon

13 sanitaire, ban, restrict*, prohib*, or clos*) as well as one travel-related term in the title or

14 abstract (travel*, cruis*, ship*, terrest*, airplane, flight, plane, migrant, passenger, return,

15 outflow, outbound, inbound, inflow, traffic, arrival, train, trains, bus, buses, transit, port*,

16 airport*, tourist*, international importation, international exportation, case importation,

17 imported cases, exported cases, or border).

\subsection{Screening strategy}

20 As of June 1, 2020, we identified a total of 312 articles, and during the review process, we

21 identified another 8 articles through other sources (see Figure 1). From all identified studies

\footnotetext{
${ }^{\mathrm{b}}$ https://www.who.int/emergencies/diseases/novel-coronavirus-2019/global-research-on-novel-coronavirus2019-ncov
} 
medRxiv preprint doi: https://doi.org/10.1101/2020.11.23.20236703; this version posted November 24, 2020. The copyright holder for this preprint (which was not certified by peer review) is the author/funder, who has granted medRxiv a license to display the preprint in perpetuity.

It is made available under a CC-BY-NC-ND 4.0 International license .

1 ( $n=320)$, we removed duplicates, which left 300 articles to be screened. We uploaded the

2 abstracts into Covidence ${ }^{c}$, software developed for systematic reviews, to perform a title and

3 abstract screen. Our inclusion criteria were that studies must investigate the COVID-19

4 pandemic and at least one travel-related measure (applied either at an international or

5 domestic border), must be empirical (i.e. modelled or observational), and must evaluate a

6 specific outcome (epidemiological or other). Measures could have been undertaken by either a

7 public (i.e. a government) or a private actor (e.g. an airline). We excluded articles that were

8 news reports, review articles, commentaries or editorials, or conjecture (i.e. did not provide

9 new data or evidence) about the effectiveness of travel measures. Each article was screened by

102 independent reviewers $(\mathrm{TLH}, \mathrm{LZH})$. Where there was disagreement among the reviewers, a

11 third reviewer (KAG) resolved any disagreement.

13 After screening, we were left with 79 articles. The full texts of each were obtained and again

14 uploaded into Covidence. Two reviewers again screened each article to determine if the article

15 still met the inclusion criteria. Any disagreements by the two reviewers were again by a third

16 reviewer (KAG) who was not otherwise involved in the screening process. After the full-text

17 screening, we were left with 30 studies that met all of our selection criteria. Of these, one study

18 investigated socio-economic outcomes, which we exclude from this analysis given the lack of

19 overlap in outcomes.

20

212.3 Updating strategy

${ }^{\mathrm{c}}$ https://www.covidence.org/ 
medRxiv preprint doi: https://doi.org/10.1101/2020.11.23.20236703; this version posted November 24, 2020. The copyright holder for this preprint (which was not certified by peer review) is the author/funder, who has granted medRxiv a license to display the preprint in perpetuity.

It is made available under a CC-BY-NC-ND 4.0 International license .

1 We continued to search the relevant databases for any newly published papers or to identify

2 papers that had originally been identified as pre-prints but were subsequently published, until 1

3 June 2020. We retained the subsequently published versions of such papers.

4

\section{$5 \quad 2.4$ Data extraction}

6 For the remaining 29 studies, we extracted the title, authors, article source, publication date,

7 whether it was a pre-print or published (or had previously been a pre-print) article, country

8 context in which the study was conducted (or global), country(ies) implementing the measure,

9 the country(ies) affected by the travel measure, specific measure(s) adopted, the timing of the

10 measures, the duration of the measures, whether the study was modeled or based on

11 observational data, the type of model used, epidemiological assumptions made in the models,

12 the specific outcomes observed, the overall findings, the way in which cases/deaths were

13 recorded, whether there was any description of diagnostic methods used to identify

14 cases/deaths, whether the study made assumptions about asymptomatic cases, whether the

15 study also accounted for secondary transmission, the extent to which the model also accounted

16 for other measures imposed around the same time, the data sources used in the study, and the

17 stated limitations of each study. For modelled studies, we also collected the name of the model

18 used if an existing model was used, whether the model used was a dynamic or static model,

19 whether the model used was a stochastic or deterministic model, and whether it was an

20 individual vs. population-based model. A full list of the papers is presented in Appendix Table 2. 
medRxiv preprint doi: https://doi.org/10.1101/2020.11.23.20236703; this version posted November 24, 2020. The copyright holder for this preprint (which was not certified by peer review) is the author/funder, who has granted medRxiv a license to display the preprint in perpetuity.

It is made available under a CC-BY-NC-ND 4.0 International license .

1 We characterized the investigated travel-related measures into four groups: suspended

2 transportation, border restrictions, entry or exit screening, and entry quarantine, which are

3 summarized in Table 1. Papers may have investigated more than one measure and thus may

4 contribute more than once to the table. In our analysis, we grouped studies according to

5 whether the measure affected international (Table 2) or domestic travellers (Table 3). One

6 study fit both criteria and thus is listed twice in the analysis. We used a narrative approach to

7 synthesize the evidence of effectiveness. Two studies, ${ }^{24,25}$ despite study design and state

8 objectives to investigate the impact of travel related measures, did not present their findings in

9 such away that allowed us to extract the evidence generated in the study. These are

10 summarized in appendix table 2 but not in tables 2 or 3.

\section{2.6. Analysis of outcome measures}

13 Outcomes included the number of observed cases, date of the epidemic peak, risk of

14 transmission, case growth rate, doubling time, time of arrival in a new country, the

15 reproductive number $\left(R_{0}\right.$ or $\left.R_{t}\right)$, and projected cumulative cases. Details are listed in Table 2 and

16 Table 3, which summarize papers that investigate international and domestic travel measures

17 respectively. One article that evaluated the effectiveness of both types of measures, ${ }^{26}$ appears

18 in both tables.

$20 \quad 2.7$ Assessment of bias

21 Individual articles were assessed for bias using a proprietary scoring system consisting of three

22 tiers: low, moderate, and high risk of bias. Low scores were given when the author had 
medRxiv preprint doi: https://doi.org/10.1101/2020.11.23.20236703; this version posted November 24, 2020. The copyright holder for this preprint (which was not certified by peer review) is the author/funder, who has granted medRxiv a license to display the preprint in perpetuity.

It is made available under a CC-BY-NC-ND 4.0 International license .

1 adequately addressed the domain, moderate when it had been either partially or incompletely

2 addressed, or high when it was not or only poorly addressed. Articles were assessed with

3 regards to their ability to form a clear and precise definition of the research question, travel

4 restriction measures included in the analysis, comprehensiveness of outcome, suitable

5 mathematical modelling, model assumptions described, confounding factors, model validation,

6 and uncertainty assessment. ${ }^{27}$ A detailed summary of our bias assessment is presented in

7 Appendix Table 1.

9 Results

10 Of the 29 identified studies in this rapid review, 24 had been published by September 1, 2020,

11 while the rest were pre-print studies (see Table 1). Almost all of the studies (26) were modelled

12 studies with few observational studies (3). Given the timing of the studies, almost all of the

13 studies focused on the initial exportation of cases from Wuhan either domestically within China

14 or internationally. Among the travel-related measures adopted, the most commonly

15 investigated were suspended transportation (24), border restrictions (21), and screening (5).

16 Only four studies investigated entry quarantine.

17

18 Effectiveness of travel-related measures on the international spread of COVID-19

19 In Table 2, we present the summary of evidence generated from the papers that investigated

20 the impact of international travel measures. All but one ${ }^{28}$ were modelled studies. Four studies

21 directly investigated the impact of the Wuhan travel ban on the initial export of cases

22 internationally. ${ }^{26,29-31}$ Comparing the observed number of exported cases to scenario-based 
medRxiv preprint doi: https://doi.org/10.1101/2020.11.23.20236703; this version posted November 24, 2020. The copyright holder for this preprint (which was not certified by peer review) is the author/funder, who has granted medRxiv a license to display the preprint in perpetuity.

It is made available under a CC-BY-NC-ND 4.0 International license .

1 modelled estimates without the ban, studies consistently found that these measures were

2 highly effective at reducing exportation of cases. Anzai et al. estimated a $70 \%$ reduction in

3 exported cases globally in the week following the introduction of the ban, ${ }^{29}$ Chinazzi et al.

4 estimated that the ban led to a $77 \%$ reduction in imported cases, ${ }^{26}$ while Wells et al. estimated

5 that it reduced the risk of exportation by about $80 \%$ through mid-February. ${ }^{30}$ Kucharski

6 estimated that transmission rates outside of China were reduced by about half in the two

7 weeks following the introduction of the ban. ${ }^{31}$ However, Anzai et al., which focused on the

8 impact of the ban on the outbreak in Japan, estimated that the absolute risk of a major

9 outbreak was only modestly delayed due to the Wuhan travel ban and that the median time

10 delay in a major outbreak was only $1-2$ days. ${ }^{29}$

12 Beyond the direct effect of the Wuhan travel ban, Chinazzi et al. estimated that the application

13 of additional travel-related restrictions, on travellers to and from Mainland China by receiving

14 countries, led to additional reductions in imported cases globally, though the extent of

15 reduction varied by country. ${ }^{26}$ Adiga et al. investigated the impact of government or airline-

16 imposed travel-related measures and estimated that these led to a delay in the importation of

17 the virus by about 4-5 days on average and up to 10 days in select countries. ${ }^{32}$ This study,

18 however, did not directly control for the impact of the Wuhan lockdown, which happened

19 around the same time as many of the measures investigated.

21 In terms of specific country case studies, Adekunle et al. found that Australia's ban on air travel

22 to and from China may have prevented $82 \%$ of imported cases through February $2 .{ }^{33}$ Similarly, 
medRxiv preprint doi: https://doi.org/10.1101/2020.11.23.20236703; this version posted November 24, 2020. The copyright holder for this preprint (which was not certified by peer review) is the author/funder, who has granted medRxiv a license to display the preprint in perpetuity.

It is made available under a CC-BY-NC-ND 4.0 International license .

1 Costantino et al. estimated that it may have led to a $79 \%$ reduction in imported cases through

2 March 2. ${ }^{34}$ Linka et al. estimated that the travel restrictions implemented both at the external

3 and internal borders of the European Union significantly decreased the speed of virus spread

4 across member states, especially in Central European countries. ${ }^{35}$ These last two studies, both

5 of which focused on an earlier period in the pandemic, failed to account for the impact of the

6 Wuhan lockdown in addition to the restrictions evaluated.

8 Studies that investigated the effectiveness of screening found that only very highly effective

9 screening could reduce [or decrease] the risk of importation or exportation. Clifford et al. found

10 that when the number of cases was low in the exporting country, screening may delay the

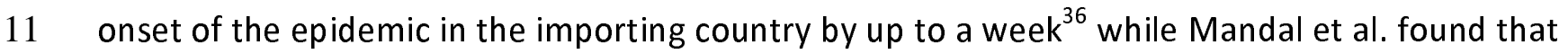

12 if screening could detect $90 \%$ of asymptomatic individuals, it could delay the average time of

13 the epidemic by up to 20 days in select countries. ${ }^{37}$ Assuming that self-identification of cases

14 was effective, another study suggested that such measures could identify a large proportion of

15 infected travellers. However, this assumes that screening is effective but does not study this

16 directly. ${ }^{30}$

17

18 A single observational study identified in this review investigated the impact of border

19 restrictions, in combination with mandatory quarantine and screening, for incoming travellers

20 to Hong Kong. Cowling et al. concluded that the application of quarantine measures of

21 incoming travellers into the region was an important element of their successful public health 
medRxiv preprint doi: https://doi.org/10.1101/2020.11.23.20236703; this version posted November 24, 2020. The copyright holder for this preprint (which was not certified by peer review) is the author/funder, who has granted medRxiv a license to display the preprint in perpetuity.

It is made available under a CC-BY-NC-ND 4.0 International license .

1 response, but the study does not specifically estimate its impact independent of other

2 measures including travel-related measures. ${ }^{28}$

3

4 Effectiveness of travel-related measures on the domestic spread of COVID-19 within China

5 In Table 3, we present the findings from the studies that investigated the impact of the Wuhan

6 travel restrictions, on the domestic export of cases to other parts of China. By comparing actual

7 observed cases to counterfactual scenarios where such measures had not been imposed,

8 Chinazzi et al. predicted that the travel ban led to a $10 \%$ reduction of exported cases within the

9 first 7 days, $^{38}$ Fang et al. estimated a $39.3 \%$ reduction over one month, ${ }^{38}$ Shi et al. similarly

10 identified a $39 \%$ reduction in cases over one month, ${ }^{39}$ while Tian et al. estimated a $73 \%$

11 reduction through mid-February. ${ }^{40}$ Tang et al. found that the Wuhan travel ban led to a $91.1 \%$

12 reduction in imported cases in Beijing over 7 days. ${ }^{41}$ Similarly, Kraemer et al. also found that

13 these travel measures dramatically reduced the transmission of the outbreak across the

14 country, with areas which had greater pre-lockdown connectivity with Wuhan experiencing a

15 greater decline. ${ }^{42}$ Aleta et al. estimated that the measures were effective in reducing the

16 exportation of cases, but only in the short term. ${ }^{43}$ Yuan also found the lockdown to be effective

17 at reducing the number of cases outside of Wuhan but notes that the timing also coincided with

18 a nationwide stay at home campaign imposed by the central Chinese government. ${ }^{44}$

20 Studies also investigated the impact of the travel ban on the domestic timing of the outbreak.

21 Tian at el. estimated the ban delayed outbreaks within China by 2.91 days, ${ }^{40}$ while Chinazzi et al.

22 estimated a delay of 3 to 5 days. ${ }^{26}$ Studies also investigated the impact of the travel ban on the 
medRxiv preprint doi: https://doi.org/10.1101/2020.11.23.20236703; this version posted November 24,2020 . The copyright holder for this preprint (which was not certified by peer review) is the author/funder, who has granted medRxiv a license to display the preprint in perpetuity.

It is made available under a CC-BY-NC-ND 4.0 International license .

1 effective reproductive rate, the doubling time, and other measures. Hou et al. found that the

2 ban quickly reduced the reproductive rate of the virus outside of Wuhan, ${ }^{45}$ similarly Li et al.

3 found that the reproductive number dropped by more than half within 2 weeks of the

4 introduction of the ban, ${ }^{46}$ Using observational data, Lau et al found that the doubling time of

5 the virus increased from 2 days to 4 days after the travel ban was imposed. ${ }^{47}$ Another study

6 found substantial declines in transmission routes between Chinese provinces within weeks of

7 the introduction of the Hubei travel bans.

9 The timing of travel-related measures, again, appears to be important in predicting

10 effectiveness. Both Lai et al. and Liu et al., the former a modelled study and the latter an

11 observational study, estimated that the Wuhan travel ban would have been substantially more

12 effective if implemented 1-3 weeks earlier. ${ }^{48,49}$ This is supported by Wu et al. who found that

13 the travel ban had a relatively minor effect on the overall speed of transmission of the outbreak

14 in areas of China outside of Wuhan, largely because a large number of cases had already been

15 exported before the travel ban, limiting its effectiveness..$^{50}$

17 Finally, a few studies evaluated domestic travel bans in combination with other travel-related

18 measures. For example, one modelled study estimated that if major cities with in China had

19 imposed additional measures, they could have further reduced their epidemic risk. ${ }^{51}$ 
medRxiv preprint doi: https://doi.org/10.1101/2020.11.23.20236703; this version posted November 24, 2020. The copyright holder for this preprint (which was not certified by peer review) is the author/funder, who has granted medRxiv a license to display the preprint in perpetuity.

It is made available under a CC-BY-NC-ND 4.0 International license .

1 Our review of the risk of bias in the included studies (Appendix Table 1) suggests that, apart

2 from a few exceptions, while most of the studies had clear research questions, descriptions of

3 the travel-related measure(s) evaluated, and discussions of the outcomes, few of the studies

4 made efforts to adequately control for the presence of other public health or travel-related

5 measures implemented at the same time, or for other contextual factors that could influence

6 the impact of travel-related measures. One important challenge common to all of the studies

7 was the quality of data on detected cases early on in the pandemic and only a small number of

8 the studies allowed for their estimates to vary based on potential ranges of the number of true

9 cases that were actually detected early in the outbreak (e.g. Chinazzi et al. estimated $24.4 \%$ of

10 all cases were undetected, ${ }^{26}$ Fang et al. estimated $42.0-80.0 \%$ were undetected, ${ }^{38}$ Kucharski et

11 al. predicted that there were at least ten times as many cases as were confirmed in Wuhan in

12 early February ${ }^{31}$ ). The studies also varied markedly in their efforts to validate their models or

13 provide uncertainty analysis around their estimates. Also, with the exception of a few studies,

14 most studies did not discuss the potential measurement error associated with case data

15 collected during the early phases of the pandemic which likely did not capture most

16 asymptomatic cases. The overall quality of the studies to evaluate effectiveness was thus

17 relatively low.

19 Discussion

20 Despite WHO's recommendations against travel restrictions, and given limited evidence of the

21 effectiveness of such measures at the onset of the COVID-19 pandemic, there has been an

22 unprecedented adoption of such measures, both domestically and internationally, which has 
medRxiv preprint doi: https://doi.org/10.1101/2020.11.23.20236703; this version posted November 24, 2020. The copyright holder for this preprint (which was not certified by peer review) is the author/funder, who has granted medRxiv a license to display the preprint in perpetuity.

It is made available under a CC-BY-NC-ND 4.0 International license .

1 led to dramatic declines in international travel. This paper reviews the emergent evidence on

2 the effectiveness of travel-measures adopted during the early phase of the COVID-19 pandemic.

4 A number of key findings emerge from this rapid review of the effectiveness of measured

5 adopted in the early phase of the pandemic. First, there was a high level of agreement among

6 the studies that the adoption of travel measures played an important role in shaping the early

7 transmission dynamics of the COVID-19 pandemic. However, almost all the studies in this

8 review focused on either domestic or international travel bans imposed on Wuhan, and to a

9 lesser extent the rest of China, during the early period of the pandemic. This review does not

10 identify substantial new evidence of the effectiveness of travel-related measures aimed at

11 controlling spread to and from other parts of the world.

13 Second, the evidence suggests that the Wuhan travel measures were likely effective at reducing

14 the initial exportation of the virus within China and abroad. At the international level, studies

15 consistently estimated that these measures led to a $70-80 \%$ reduction in cases exported in the

16 first few weeks, and likely had a smaller effect within Mainland China, where estimates of

17 effectiveness ranged from $10-70 \%$. Also, the Wuhan travel ban likely led to delays of up to a

18 few weeks in the importation of cases to other countries. However, most of the studies also

19 concurred that the effects were short-lived. This suggests travel-related measures alone are

20 unlikely to significantly change the trajectory of the outbreak unless commensurate domestic

21 measures are also implemented. This is supported by evidence that once four or more 
medRxiv preprint doi: https://doi.org/10.1101/2020.11.23.20236703; this version posted November 24, 2020. The copyright holder for this preprint (which was not certified by peer review) is the author/funder, who has granted medRxiv a license to display the preprint in perpetuity.

It is made available under a CC-BY-NC-ND 4.0 International license .

1 infections are introduced into a new location, there is an over $50 \%$ chance that a major

2 outbreak will occur. ${ }^{31}$

3

4 Third, the studies reviewed suggest a key factor influencing the effectiveness of travel-related

5 measures was timing. Within China, had the same policies been implemented a few weeks

6 earlier, it is likely there may have been substantially less seeding of new outbreaks across the

7 country and internationally. While the measures aimed at Wuhan significantly reduced the

8 exportation of cases from the province, over time other provinces became the source of most

9 of the internationally exported cases. Where authorities are not able or willing to adopt such

10 measures at a sufficiently early stage of an outbreak, once again, this suggests the need to give

11 commensurate attention to strengthening the role of other domestic measures such as testing,

12 contact tracing, and physical distancing.

14 Fourth, many of the studies focused on international travel failed to account for the

15 implementation of the domestic Wuhan travel ban. Although this was a domestic policy, and

16 thus outside the remit of the IHR, evidence suggests restricting travel to and from Wuhan

17 dramatically changed the outflow of cases from the region at a crucial time period. Studies that

18 did not account for the Wuhan travel ban in their estimates, or reviews that excluded domestic

19 travel measures, thus likely overestimated the effectiveness of international travel measures.

20 The notable exception was Chinazzi et al. who conclude that the additional measures provided

21 a benefit above and beyond the effect of the Wuhan measures, at least in the short run. ${ }^{26}$ 
medRxiv preprint doi: https://doi.org/10.1101/2020.11.23.20236703; this version posted November 24, 2020. The copyright holder for this preprint (which was not certified by peer review) is the author/funder, who has granted medRxiv a license to display the preprint in perpetuity.

It is made available under a CC-BY-NC-ND 4.0 International license .

1 Fifth, during the early phase of the pandemic there were likely large numbers of undetected

2 cases globally, and although some studies allowed for their estimates to vary based on assumed

3 proportions of undetected cases, the validity of the estimated effects in all of these studies is

4 likely affected by data quality issues. Also, given that symptomatic individuals may be more

5 likely to curb their travel than asymptomatic travellers, especially internationally and after the

6 introduction of travel-related measures aimed at detecting symptomatic cases, modelled

7 effectiveness studies may also be biased if they do not account for this difference. In addition,

8 it is also possible that some of the travel-related measures adopted (e.g. screening) could have

9 actually led to increased detection of cases, ${ }^{46}$ which could further complicate the ability of

10 studies to evaluate effectiveness as the measurement of the outcome is influenced by the

11 intervention itself and few studies acknowledged this limitation.

13 Finally, while this study identified a relatively large number of studies, we assess the quality of

14 these studies overall to be low. Almost all of the studies identified in this review were

15 modelled studies, and therefore the results depend upon important parameter assumptions,

16 which varied considerably. Given the rapidly evolving and dynamic nature of the pandemic, it is

17 unclear how close to reality these assumptions were. Comparability across the studies is also

18 undermined by a lack of standardized terminology. Furthermore, few studies attempted to

19 isolate the potential effect of international travel-related measures from a range of domestic

20 measures implemented concurrently, as well as from other social, political, or economic

21 characteristics of the implementing or target locations or populations. 
medRxiv preprint doi: https://doi.org/10.1101/2020.11.23.20236703; this version posted November 24, 2020. The copyright holder for this preprint (which was not certified by peer review) is the author/funder, who has granted medRxiv a license to display the preprint in perpetuity.

It is made available under a CC-BY-NC-ND 4.0 International license .

1 This systematic review also has several important limitations of its own. First, while we aimed

2 to be systematic in our search strategy as well as inclusion criteria, the rapidly expanding

3 literature on COVID-19 pandemic almost certainly means that we likely overlooked some

4 relevant studies. Second, although we aimed to focus on the early phase of the outbreak, it is

5 unclear when the appropriate time was to end our review. Newer studies that have been

6 published since we ended searching the literature may present a different picture on the

7 effectiveness of travel measures and thus the evidence from this study must be evaluated in

8 this context. Third, assessments of bias in studies is challenging and is inherently subjective in

9 nature.

10

11 In recent months, a process has commenced to review and strengthen the IHR. The universal

12 use of travel-related measures by States Parties during the COVID-19 pandemic will be a major

13 focus of discussion on the limitations of the current treaty. Based on this review, we make the

14 following recommendations. First, the findings of this review suggest that it is difficult to know

15 in the early phases of an infectious disease outbreak how effective travel measures are likely to

16 be, based on evidence from previous studies. Overall, the findings of the review suggest that

17 while it is likely that travel measures can affect the early dynamics of an infectious disease

18 outbreak, their effectiveness in delaying or reducing international spread is likely to be limited

19 on their own and short-lived. But the review also finds that the way in which these measures

20 are adopted likely influences their effectiveness. This highlights the need to from blanket

21 assessments of the effectiveness of travel-related measures ("travel measures don't work"), to 
medRxiv preprint doi: https://doi.org/10.1101/2020.11.23.20236703; this version posted November 24,2020 . The copyright holder for this preprint (which was not certified by peer review) is the author/funder, who has granted medRxiv a license to display the preprint in perpetuity.

It is made available under a CC-BY-NC-ND 4.0 International license .

1 context-specific assessments of effectiveness based on scenarios of transmission risk ("when

2 might such measures be effective"?).

4 Second, it is also clear that the effectiveness of travel-measures cannot be estimated using a

5 single fixed parameter. The effectiveness of measures will vary based on the setting, which

6 other measures are also implemented, the extent to which they are implemented, and the

7 speed at which they are implemented. All of these factors, weighed against potential harms,

8 need to be taken into consideration in discussions about the potential effectiveness of

9 international travel measures.

10

11 Third, this study finds that measures implemented early were likely more effective than those

12 implemented late. In this pandemic, the WHO did not make any recommendations on travel

13 restrictions until it had issued the PHEIC, weeks after when many countries had already

14 implemented such measures, and when it did, it had recommended against such measures

15 based on the limited evidence available at the time. In addition, the IHR require State Parties to

16 provide evidence for any additional health measures that they implement. In the context of an

17 outbreak of a novel infectious disease agent, it is unclear what justifies evidence in the early

18 phases of the outbreak. The role of evidence in the IHR in such settings therefore needs to be

19 reconsidered.

20

21 This review also highlights areas where more research is urgently needed to understand the

22 appropriate role of travel measures during PHEICs. First, a greater understanding of 
medRxiv preprint doi: https://doi.org/10.1101/2020.11.23.20236703; this version posted November 24, 2020. The copyright holder for this preprint (which was not certified by peer review) is the author/funder, who has granted medRxiv a license to display the preprint in perpetuity.

It is made available under a CC-BY-NC-ND 4.0 International license .

1 effectiveness of travel measures adopted globally, and at stages beyond the early phases of the

2 pandemic are urgently needed. Second, there is also a need to better understand the broad

3 range of measures affecting travel and trade beyond those covered in the reviewed studies,

4 including the role of testing, which was not widely available during the early phase of the

5 pandemic. Third, lack of data on true case numbers remains an underlying challenge across all

6 of the study reviewed, and thus needs to be taken more seriously in future studies. Fourth,

7 models need to better account for the way in which travel measures work in tandem with other

8 measures implemented concurrently, including domestic travel measures and other public

9 health measures. Fifth, studies need to better account for the possibility that some locations

10 see grater benefit from travel measures than others based on geographic and socioeconomic

11 factors. Finally, one of the rationales against the use of travel measures is their economic and

12 social impacts, yet few studies in the early phases evaluated their non-epidemiological

13 outcomes.

14

15 At the onset of the COVID-19 pandemic, there was a widely held belief that travel measures

16 were unlikely to play much of a role in curbing international spread of the virus. However, the

17 widespread adoption, and persistent use of such measures, globally, as well as some of the

18 evidence identified in this review, challenge this belief. While this review emphasizes that the

19 quality of evidence remains low and highlights a number of methodological shortcomings in the

20 reviewed studies, this review also identified new evidence of the impact of such measures

21 during the early phase of the pandemic. These findings suggest such measures did play an

22 important role in shaping early dynamics of the pandemic, even if they were unable to contain 
medRxiv preprint doi: https://doi.org/10.1101/2020.11.23.20236703; this version posted November 24, 2020. The copyright holder for this preprint (which was not certified by peer review) is the author/funder, who has granted medRxiv a license to display the preprint in perpetuity. It is made available under a CC-BY-NC-ND 4.0 International license .

1 the virus globally on their own. Like with so many things that COVID-19 has transformed, and

2 the pandemic has also challenged our views of what constitutes evidence of effectiveness of

3 public health measures. ${ }^{52}$

4 
medRxiv preprint doi: https://doi.org/10.1101/2020.11.23.20236703; this version posted November 24, 2020. The copyright holder for this preprint (which was not certified by peer review) is the author/funder, who has granted medRxiv a license to display the preprint in perpetuity.

It is made available under a CC-BY-NC-ND 4.0 International license .

\section{Role of the Funding Agency}

2 The authors are funded by the New Frontiers in Research Fund (Grant NFRFR-2019-00009)

3 through an operating grant awarded under the Canadian Institutes of Health Research Rapid

4 Research Funding Opportunity. The funders were not involved in the design or writing of this

5 study.

6

7 Contributions

$8 \quad$ KG developed the study methodology, drafted the manuscript, and oversaw data analysis. ZL

9 and TLH conducted the systematic review search, article screening, data extraction, and data

10 analysis. $\mathrm{KL}, \mathrm{CZW}$, and SM contributed to the design of the study and provided input into the

11 manuscript.

12

\section{Conflicts of interest}

14 KL was a member of two donor-funded reviews of WHO in 1995 and 1997. She has previously

15 received funding from WHO to conduct research on global health governance and global

16 tobacco control, and review evidence on the impacts of globalization and infectious diseases.

17 CZW was a member of a WHO guideline development group and technical consultation in 2019. 


\section{References}

1. WHO. Statement on the second meeting of the International Health Regulations (2005) Emergency Committee regarding the outbreak of novel coronavirus (2019-nCoV). https://www.who.int/news/item/30-01-2020-statement-on-the-second-meeting-of-theinternational-health-regulations-(2005)-emergency-committee-regarding-the-outbreak-ofnovel-coronavirus-(2019-ncov) (2020).

2. Control, T. C. for D. In response to pneumonia outbreak in Wuhan, China and related test

9 results, Taiwan CDC remains in touch with China and World Health Organization and Taiwan

10 maintains existing disease control and prevention efforts Facebookshare to Facebook(open in

11 new window)Lineshare to Line(open in new window)Printprint(open in new window).

12 https://www.cdc.gov.tw/En/Bulletin/Detail/4N96uF-2yK-d7dEFFcwa0Q?typeid=158 (2020).

13 3. Levenson, M. Scale of China's Wuhan Shutdown Is Believed to Be Without Precedent. (2020).

14 4. Lee, K., Worsnop, C. Z., Grépin, K. A. \& Kamradt-Scott, A. Global coordination on cross-border

15 travel and trade measures crucial to COVID-19 response. Lancet (2020) doi:10.1016/s0140-

16 6736(20)31032-1.

17 5. Worsnop, C. Z. Concealing Disease: Trade and Travel Barriers and the Timeliness of Outbreak

18 Reporting. Int Stud Perspect 20, 344-372 (2019).

19 6. Rhymer, W. \& Speare, R. Countries' response to WHO's travel recommendations during the

20 2013-2016 Ebola outbreak. B World Health Organ 95, 10-17 (2016).

21 7. Worsnop, C. Z. Provoking Barriers: The 2014 Ebola Outbreak and Unintended Consequences

22 of WHO's Power to Declare a Public Health Emergency. Global Health Governance XI, 1-26

23 (2017).

24 8. UNWTO. UNWTO World Tourism Barometer. 18, (2020).

25 9. Ryu, S. et al. Nonpharmaceutical Measures for Pandemic Influenza in Nonhealthcare

26 Settings - International Travel-Related Measures. Emerg Infect Dis 26, 961-966 (2020).

27 10. WHO. Non-pharmaceutical public health measures for mitigating the risk and impact of

28 epidemic and pandemic influenza. (2019).

29 11. Mateus, A. L., Otete, H. E., Beck, C. R., Dolan, G. P. \& Nguyen-Van-Tam, J. S. Effectiveness of

30 travel restrictions in the rapid containment of human influenza: a systematic review. $B$ World

31 Health Organ 92, 868-880D (2014). 
medRxiv preprint doi: https://doi.org/10.1101/2020.11.23.20236703; this version posted November 24, 2020. The copyright holder for this preprint (which was not certified by peer review) is the author/funder, who has granted medRxiv a license to display the preprint in perpetuity.

It is made available under a CC-BY-NC-ND 4.0 International license .

1 12. Poletto, C. et al. Assessing the impact of travel restrictions on international spread of the

22014 West African Ebola epidemic. Eurosurveillance 19, (2014).

3 13. Bogoch, I. I. et al. Assessment of the potential for international dissemination of Ebola virus

4 via commercial air travel during the 2014 west African outbreak. Lancet 385, 29-35 (2014).

5 14. Otsuki, S. \& Nishiura, H. Reduced Risk of Importing Ebola Virus Disease because of Travel

6 Restrictions in 2014: A Retrospective Epidemiological Modeling Study. Plos One 11, e0163418

7 (2016).

8 15. Hollingsworth, T. D., Ferguson, N. M. \& Anderson, R. M. Will travel restrictions control the

9 international spread of pandemic influenza? Nat Med 12, 497-499 (2006).

10 16. Nuzzo, J. B., Cicero, A. J., Waldhorn, R. \& Inglesby, T. V. Travel Bans Will Increase the

11 Damage Wrought by Ebola. Biosecurity Bioterrorism Biodefense Strategy Pract Sci 12, 306-309

12 (2014).

13 17. Vaidya, R., Herten-Crabb, A., Spencer, J., Moon, S. \& Lillywhite, L. Travel restrictions and

14 infectious disease outbreaks. J Travel Med (2020) doi:10.1093/jtm/taaa050.

15 18. He, X. et al. Temporal dynamics in viral shedding and transmissibility of COVID-19. Nat Med

$1626,672-675$ (2020).

17 19. Anderson, R. M., Heesterbeek, H., Klinkenberg, D. \& Hollingsworth, T. D. How will country-

18 based mitigation measures influence the course of the COVID-19 epidemic? Lancet (2020)

19 doi:10.1016/s0140-6736(20)30567-5.

20 20. Tigerstrom, B. von \& Wilson, K. COVID-19 travel restrictions and the International Health

21 Regulations (2005). Bmj Global Heal 5, e002629 (2020).

22 21. Worsnop, C. Z. et al. Legal compliance is not enough: cross-border travel and trade

23 measures and COVID-19. (2020).

24 22. Group, P.-P. et al. Preferred reporting items for systematic review and meta-analysis

25 protocols (PRISMA-P) 2015 statement. Syst Rev 4, 1 (2015).

26 23. Iacus, S. M., Natale, F., Santamaria, C., Spyratos, S. \& Vespe, M. Estimating and Projecting

27 Air Passenger Traffic during the COVID-19 Coronavirus Outbreak and its Socio-Economic Impact.

28 Safety Sci 104791 (2020) doi:10.1016/j.ssci.2020.104791.

29 24. Boldog, P. et al. Risk Assessment of Novel Coronavirus COVID-19 Outbreaks Outside China. J

30 Clin Medicine 9, 571 (2020). 
medRxiv preprint doi: https://doi.org/10.1101/2020.11.23.20236703; this version posted November 24, 2020. The copyright holder for this preprint (which was not certified by peer review) is the author/funder, who has granted medRxiv a license to display the preprint in perpetuity.

It is made available under a CC-BY-NC-ND 4.0 International license .

1 25. Klausner, Z., Fattal, E., Hirsch, E. \& Shapira, S. C. A single holiday was the turning point of the

2 COVID-19 policy of Israel. Medrxiv 2020.03.26.20044412 (2020)

3 doi:10.1101/2020.03.26.20044412.

4 26. Chinazzi, M. et al. The effect of travel restrictions on the spread of the 2019 novel

5 coronavirus (COVID-19) outbreak. Science eaba9757 (2020) doi:10.1126/science.aba9757.

6 27. Pitman, R. et al. Dynamic Transmission Modeling. Med Decis Making 32, 712-721 (2012).

7 28. Cowling, B. J. et al. Impact assessment of non-pharmaceutical interventions against

8 coronavirus disease 2019 and influenza in Hong Kong: an observational study. Lancet Public

9 Heal 5, e279-e288 (2020).

10 29. Anzai, A. et al. Assessing the Impact of Reduced Travel on Exportation Dynamics of Novel

11 Coronavirus Infection (COVID-19). J Clin Medicine 9, 601 (2020).

12 30. Wells, C. R. et al. Impact of international travel and border control measures on the global

13 spread of the novel 2019 coronavirus outbreak. Proc National Acad Sci 117, 7504-7509 (2020).

14 31. Kucharski, A. J. et al. Early dynamics of transmission and control of COVID-19: a

15 mathematical modelling study. Lancet Infect Dis 20, 553-558 (2020).

16 32. Evaluating the impact of international airline suspensions on the early global spread of

17 COVID-19. (n.d.).

18 33. Adekunle, A. I., Meehan, M., Alvarez, D. R., Trauer, J. \& McBryde, E. Delaying the COVID-19

19 epidemic in Australia: Evaluating the effectiveness of international travel bans. (n.d.)

20 doi:10.1101/2020.03.22.20041244.

21 34. Costantino, V., Heslop, D. J. \& Macintyre, C. R. The effectiveness of full and partial travel

22 bans against COVID-19 spread in Australia for travellers from China. Medrxiv

232020.03 .09 .20032045 (2020) doi:10.1101/2020.03.09.20032045.

24 35. Linka, K., Peirlinck, M., Costabal, F. S. \& Kuhl, E. Outbreak dynamics of COVID-19 in Europe

25 and the effect of travel restrictions. Comput Method Biomec 1-8 (2020)

26 doi:10.1080/10255842.2020.1759560.

27 36. Clifford, S. et al. Effectiveness of interventions targeting air travellers for delaying local

28 outbreaks of SARS-CoV-2. J Travel Med taaa068- (2020) doi:10.1093/jtm/taaa068.

29 37. Mandal, S. et al. Prudent public health intervention strategies to control the coronavirus

30 disease 2019 transmission in India: A mathematical model-based approach. Indian J Med Res 0,

310 (2020). 
medRxiv preprint doi: https://doi.org/10.1101/2020.11.23.20236703; this version posted November 24, 2020. The copyright holder for this preprint (which was not certified by peer review) is the author/funder, who has granted medRxiv a license to display the preprint in perpetuity.

It is made available under a CC-BY-NC-ND 4.0 International license .

1 38. FANG, H., WANG, L. \& YANG, Y. Human Mobility Restrictions and the Spread of the Novel

2 Coronavirus (2019-nCoV) in China. Medrxiv 2020.03.24.20042424 (2020)

3 doi:10.1101/2020.03.24.20042424.

4 39. Shi, Z. \& Fang, Y. Temporal relationship between outbound traffic from Wuhan and the

52019 coronavirus disease (COVID-19) incidence in China. Medrxiv 2020.03.15.20034199 (2020)

6 doi:10.1101/2020.03.15.20034199.

7 40. Tian, H. et al. An investigation of transmission control measures during the first 50 days of

8 the COVID-19 epidemic in China. Science 368, 638-642 (2020).

9 41. Tang, B. et al. Estimation of the Transmission Risk of the 2019-nCoV and Its Implication for

10 Public Health Interventions. J Clin Medicine 9, 462 (2020).

11 42. Kraemer, M. U. G. et al. The effect of human mobility and control measures on the COVID-

1219 epidemic in China. Science 368, 493-497 (2020).

13 43. Aleta, A., Hu, Q., Ye, J., Ji, P. \& Moreno, Y. A data-driven assessment of early travel

14 restrictions related to the spreading of the novel COVID-19 within mainland China. Chaos

15 Solitons Fractals 139, 110068 (2020).

16 44. zheming, Y. \& Yuan, C. A simple model to assess Wuhan lock-down effect and region efforts

17 during COVID-19 epidemic in China Mainland. Medrxiv 2020.02.29.20029561 (2020)

18 doi:10.1101/2020.02.29.20029561.

19 45. Hou, J. et al. Changing transmission dynamics of COVID-19 in China: a nationwide

20 population-based piecewise mathematical modelling study. Medrxiv 2020.03.27.20045757

21 (2020) doi:10.1101/2020.03.27.20045757.

22 46. Li, R. et al. Substantial undocumented infection facilitates the rapid dissemination of novel

23 coronavirus (SARS-CoV-2). Science 368, 489-493 (2020).

24 47. Lau, H. et al. The positive impact of lockdown in Wuhan on containing the COVID-19

25 outbreak in China. J Travel Med 27, (2020).

26 48. Lai, S. et al. Effect of non-pharmaceutical interventions to contain COVID-19 in China.

27 Nature 1-4 (2020) doi:10.1038/s41586-020-2293-x.

28 49. Liu, K. et al. Population Movement, City Closure in Wuhan, and Geographical Expansion of

29 the COVID-19 Infection in China in January 2020. Clin Infect Dis (2020) doi:10.1093/cid/ciaa422.

30 50. Wu, J. T., Leung, K. \& Leung, G. M. Nowcasting and forecasting the potential domestic and 31 international spread of the 2019-nCoV outbreak originating in Wuhan, China: a modelling study.

32 Lancet 395, 689-697 (2020). 
medRxiv preprint doi: https://doi.org/10.1101/2020.11.23.20236703; this version posted November 24, 2020. The copyright holder for this preprint (which was not certified by peer review) is the author/funder, who has granted medRxiv a license to display the preprint in perpetuity. It is made available under a CC-BY-NC-ND 4.0 International license .

1 51. Su, L. et al. Evaluation of the Secondary Transmission Pattern and Epidemic Prediction of 2 COVID-19 in the Four Metropolitan Areas of China. Frontiers Medicine 7, 171 (2020).

3 52. Greenhalgh, T. Will COVID-19 be evidence-based medicine's nemesis? Plos Med 17, 4 e1003266 (2020). 
Figumedpxivppreprintoi: https://doi.org/10.1101/2020.11.23.20236703; this version posted November 24, 2020. The copyright holder for this preprint (which was not certified by peer review) is the author/funder, who has granted medRxiv a license to display the preprint in perpetuity.

It is made available under a CC-BY-NC-ND 4.0 International license .

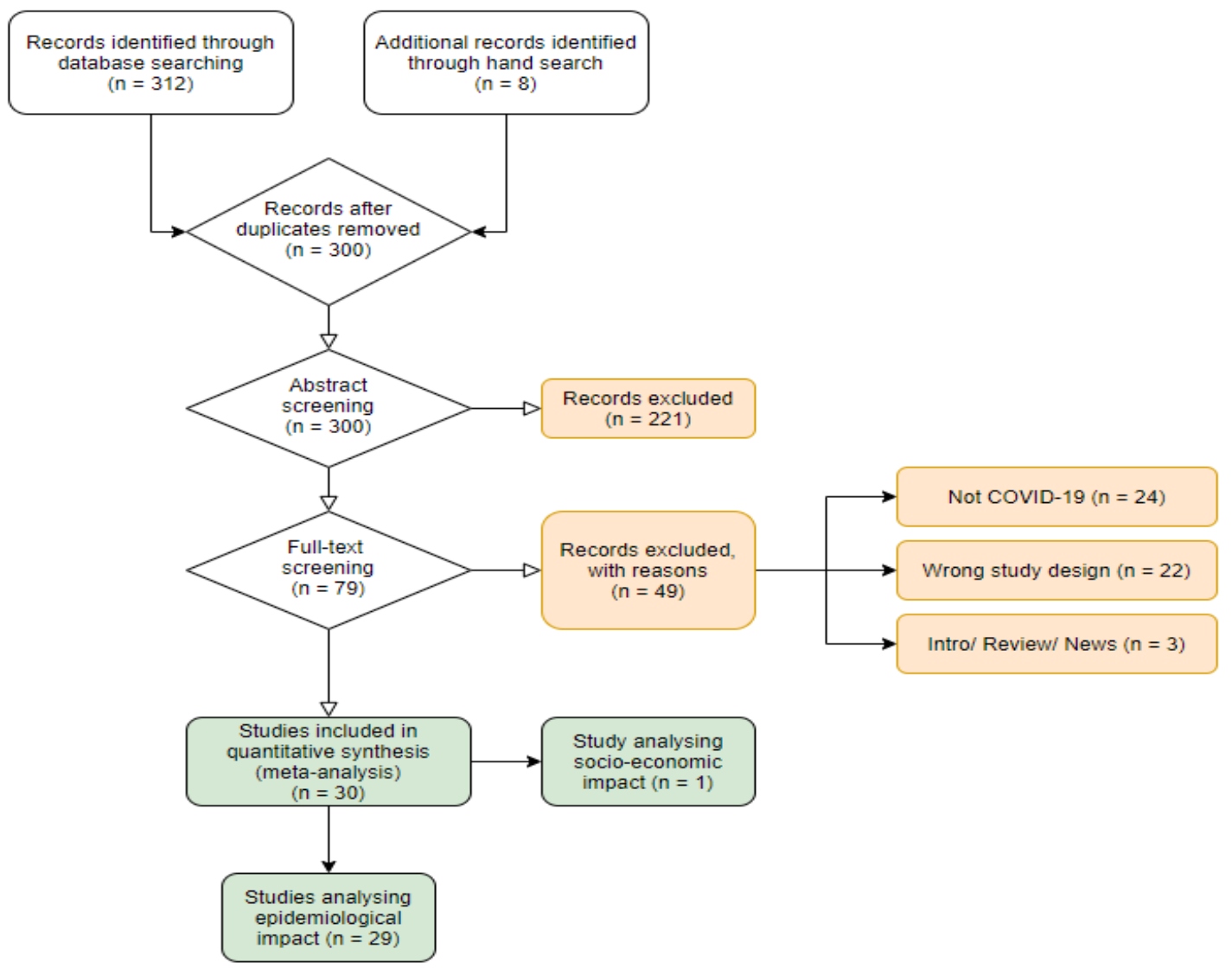


TabmedPxivprepriptd døi.inttps://doi.org/10.1101/2020.11.23.20236703; this version posted November 24, 2020. The copyright holder for this

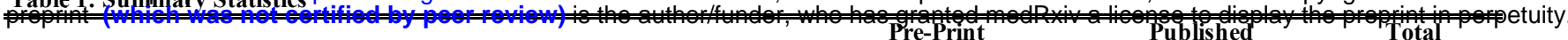

Date of pre-print submission/ publicatibis made available under a CC-BY-NC-ND 4.0 International license .

January

February

March

April

May

Study design

Modelled

Observational

Level of region affected by travel measures

Mainland China

Other single country

Multi-countries or global

Level of travel measures imposed

International

Interprovincial

Both $^{\mathrm{a}}$

Travel measures analysed $^{\mathbf{b}}$

Suspended transportation

Border restrictions

Screening

Entry quarantine

Note:

a papers evaluating the impact of both international and interprovincial measures.

${ }^{\mathrm{b}}$ papers may analyse effects of multiple restrictions.
0

0

\section{1}

4

11

1

5

21

3

0

14

4

6

5

$2 \quad 10 \quad 12$

$3-13 \quad 16$

$0+1$

$4 \quad 20 \quad 24$

$3 \quad 18 \quad 21$

$0 \quad 5 \quad 5$

$1 \quad 3 \quad 4$

3

6

1

5




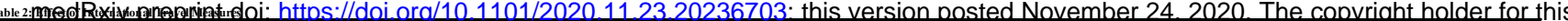

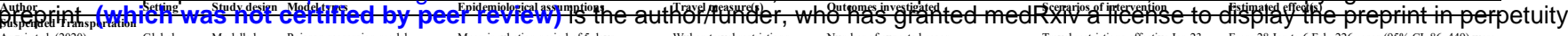

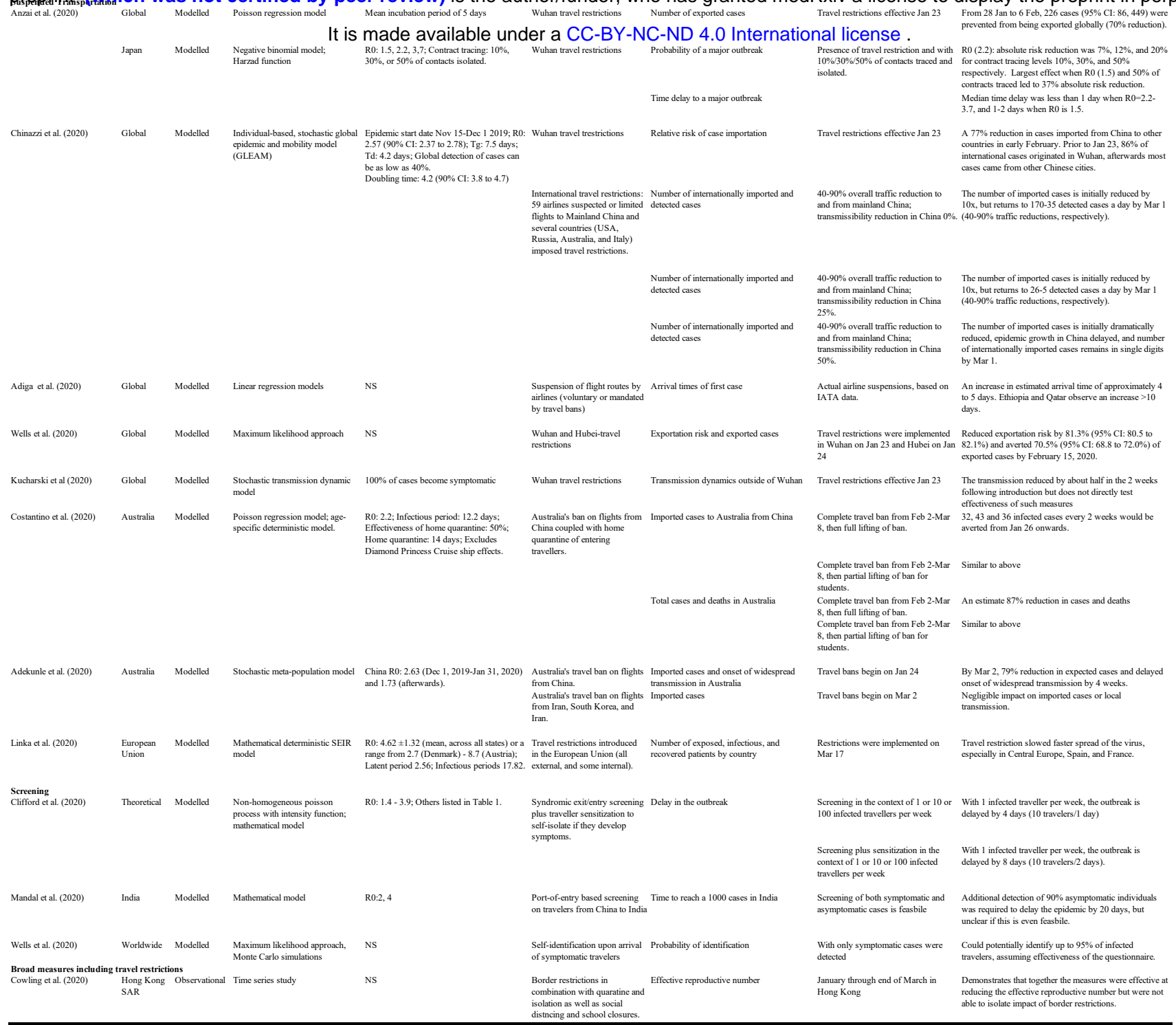


medRxiv preprint doi: https://doi.org/10.1101/2020.11.23.20236703; this version posted November 24, 2020. The copyright holder for this preprint (which was not certified by peer review) is the author/funder, who has granted medRxiv a license to display the preprint in perpetuity.

It is made available under a CC-BY-NC-ND 4.0 International license .

\begin{tabular}{|c|c|c|c|c|c|c|c|}
\hline Author & Study design & Model type & Epidemiological assumptions & Travel measure(s) & Outcomes investigated & Scenarios of Intervention & Estimated effect(s) \\
\hline $\begin{array}{l}\text { Aleta et al. (2020) } \\
\end{array}$ & 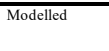 & $\begin{array}{l}\text { Stochastic SEIR-metapopulation } \\
\text { model }\end{array}$ & $\begin{array}{l}\text { Generation time: } 7.5 \text { days; } \mathrm{R} 0: 2.4 ; \\
\text { later period: } 3 \text { days }\end{array}$ & $\begin{array}{l}\text { Wuhan travel measures } \\
\end{array}$ & $\begin{array}{l}\text { Cases in Mainland China } \\
\text { outside of Wuhan }\end{array}$ & $\begin{array}{l}\text { Travel measures implemented on Jan } 23 \\
\end{array}$ & $\begin{array}{l}\text { A reduced reduced number of cases but only in } \\
\text { the short term. }\end{array}$ \\
\hline \multirow[t]{2}{*}{$\begin{array}{l}\text { Chinazzi et al. } \\
(2020)\end{array}$} & \multirow[t]{2}{*}{ Modelled } & \multirow[t]{2}{*}{$\begin{array}{l}\text { Individual-based, stochastic } \\
\text { global epidemic and mobility } \\
\text { model (GLEAM) }\end{array}$} & \multirow[t]{2}{*}{$\begin{array}{l}\text { R0: } 2.57 \text {; doubling time: } 4.2 ; \text { no } \\
\text { changes in transmissibility within } \\
\text { China }\end{array}$} & \multirow[t]{2}{*}{ Wuhan travel measures } & $\begin{array}{l}\text { Cases in Mainland China } \\
\text { outside of Wuhan }\end{array}$ & \multirow[t]{2}{*}{ Travel measures implemented on Jan 23} & $\begin{array}{l}\text { Reduction of cases was approximately } 10 \% \text { by } \\
31 \text { January (range } 1 \text { to } 58 \% \text { ). }\end{array}$ \\
\hline & & & & & Timing of epidemic peak & & $\begin{array}{l}\text { Wuhan travel ban delayed epidemic progression } \\
\text { by } 3 \text { to } 5 \text { days in China. }\end{array}$ \\
\hline Fang et al. (2020) & Modelled & $\begin{array}{l}\text { Dynamic distributed lag } \\
\text { regression model }\end{array}$ & Incubation period: up to 22 days & Wuhan travel measures & $\begin{array}{l}\text { Number of cases in cities } \\
\text { outside of Hubei from Jan } \\
23 \text {-Feb } 29\end{array}$ & Travel measures implemented on Jan 23 & $\begin{array}{l}\text { COVID-19 cases would be } 64.81 \% \text { higher in } \\
347 \text { cities outside Hubei }(20,810 \mathrm{v} .12,626) \text {, and } \\
52.64 \% \text { higher in } 16 \text { other cities in Hubei as of } \\
29 \text { February }(23,400 \mathrm{v} .15,330) \text {. }\end{array}$ \\
\hline Shi et al. (2020) & Modelled & $\begin{array}{l}\text { Autoregressive integrated } \\
\text { moving average (ARIMA) } \\
\text { model }\end{array}$ & Incubation period: 4-6 days & Wuhan travel measures & $\begin{array}{l}\text { Cumulative number of } \\
\text { confrimed cases outside } \\
\text { Wuhan by Feb } 29\end{array}$ & Travel measures implemented on Jan 23 & $\begin{array}{l}\text { Travel ban may have prevented approximately } \\
19,768 \text { ( } 95 \% \text { CI: } 13589,25946) \text { cases outside of } \\
\text { Wuhan by Feb } 29(39 \% \text { reduction). }\end{array}$ \\
\hline Tian et al. (2020) & Modelled & Deterministic SEIR model & $\mathrm{R} 0: 3.15$ & Wuhan travel measures & $\begin{array}{l}\text { Arrival times in cities across } \\
\text { Mainland China by Feb } 19 \\
\text { Cases in Mainland China } \\
\text { outside of Wuhan by Feb } 19\end{array}$ & Travel measures implemented on Jan 23 & $\begin{array}{l}\text { Delayed arrival time by } 2.91 \text { days }(95 \% \mathrm{Cl} \text { : } \\
2.54,3.29) \text {. } \\
\text { National number of cases decreased from } \\
744,000( \pm 156,000) \text { to } 202,000( \pm 10,000) \\
(72.8 \% \text { decrease }) \text {. }\end{array}$ \\
\hline $\begin{array}{l}\text { Kraemer et al } \\
(2020)\end{array}$ & Modelled & Generalized linear model & $\begin{array}{l}\text { Doubling time: } 4.0 \text { days (outside } \\
\text { Hubei), } 7.2 \text { days (inside Hubei); } \\
\text { incubation period } 5.1 \text { days }\end{array}$ & Wuhan travel measures & $\begin{array}{l}\text { Cases in Mainland China } \\
\text { outside of Wuhan by end of } \\
\text { Feb }\end{array}$ & Travel measures implemented on Jan 23 & $\begin{array}{l}\text { Travel measures reduced growth rates outside, } \\
\text { which became negative after Jan } 23 ; \text { Provinces } \\
\text { with greater mobility from Wuhan displayed } \\
\text { more rapidly declining growth rates. }\end{array}$ \\
\hline Tang et al. (2020) & Modelled & Deterministic SEIR model & $\mathrm{R} 0: 6.47$ & Wuhan travel measures & $\begin{array}{l}\text { Cases in select locations } \\
\text { outside of Wuhan }\end{array}$ & Travel measures implemented on Jan 23 & $\begin{array}{l}\text { Travel restriction reduced the number of } \\
\text { infected individuals in Beijing over } 7 \text { days by } \\
91.14 \% \text {. }\end{array}$ \\
\hline Hou et al. (2020) & Modelled & Deterministic SEIR model & Incubation period: 7 days & Wuhan travel measures & Effective reproductive rate & Travel measures implemented on Jan 23 & $\begin{array}{l}\text { Travel measures signficiantly changed } \\
\text { transmission dynamics within China }\end{array}$ \\
\hline Liet al. (2020) & Modelled & Stochastic SEIR model & $\begin{array}{l}\mathrm{R} 0 \text { at the beginning of the epidemic to } \\
\text { be } 2.38\end{array}$ & Wuhan travel measures & Reproductive number & Travel measures implemented on Jan 23 & $\begin{array}{l}\text { Travel measure reduced the reproductive } \\
\text { number from } 2.38 \text { down to } 1.34 \text { and } 0.98 \text {, in the } \\
1 \text { and } 2 \text { week period immediately following their } \\
\text { introduction. }\end{array}$ \\
\hline Lau et al. (2020) & Observational & Retrospective regression model & $\begin{array}{l}\text { R0: } 2.2-3.9: \text { mean incubation period: } \\
5.1 \text { days }\end{array}$ & Wuhan travel measures & Doubling time & Travel measures implemented on Jan 23 & $\begin{array}{l}\text { Significant increase in doubling time from } 2 \text { to } 4 \\
\text { days after lockdown. }\end{array}$ \\
\hline Wu et al. (2020) & Modelled & Deterministic SEIR model & $\begin{array}{l}\mathrm{R} 0=2.6 \text {, zoonotic force }=86 / \text { day until } \\
\text { Jan } 1 \text { market closure }\end{array}$ & Wuhan travel measures & $\begin{array}{l}\text { Exported cases in the rest of } \\
\text { Mainland China }\end{array}$ & $\begin{array}{l}\text { Travel restrictions led to either a } 0 \% \text { or } \\
50 \% \text { reduction in travel outside of Wuhan }\end{array}$ & $\begin{array}{l}\text { Even a } 50 \% \text { reduction in inter-city mobility } \\
\text { would have a negligible effect on the epidemic } \\
\text { dynamics. }\end{array}$ \\
\hline \multirow[t]{3}{*}{ Liu et al. (2020) } & \multirow[t]{3}{*}{ Observational } & \multirow[t]{3}{*}{ Linear regression } & \multirow[t]{3}{*}{ Incubation period: $3-7$ days } & \multirow[t]{3}{*}{ Wuhan travel measures } & \multirow[t]{3}{*}{$\begin{array}{l}\text { Cases exported outside of } \\
\text { Wuhan }\end{array}$} & Travel measures implemented on Jan 23 & $\begin{array}{l}\text { A mean values of } 129 \text { cases exported per } 10,000 \\
\text { people who left Wuhan }\end{array}$ \\
\hline & & & & & & Travel measures implmented 2 days earlier & $\begin{array}{l}\text { An estimated } 1420(95 \% \text { CI: } 1059,1833) \text { cases } \\
\text { would have been prevented. }\end{array}$ \\
\hline & & & & & & Travel measures implmented 2 days later & $\begin{array}{l}\text { An estimated } 1462(95 \% \text { CI: } 1059,1833) \\
\text { additional cases would have happened. }\end{array}$ \\
\hline \multirow[t]{2}{*}{ Yuan et al. (2020) } & \multirow[t]{2}{*}{ Modelled } & \multirow[t]{2}{*}{ Regression model } & \multirow[t]{2}{*}{ Incubation period: 5 days } & \multirow[t]{2}{*}{$\begin{array}{l}\text { Wuhan travel measures in } \\
\text { combination with a stay at } \\
\text { home movement }\end{array}$} & $\begin{array}{l}\text { Cases in } 44 \text { regions outside } \\
\text { of Wuhan by Feb } 27\end{array}$ & Travel measures implemented on Jan 23 & $\begin{array}{l}\text { Reduced the nunmber of cases outside of Wuhan } \\
\text { from } 41,477 \text { to } 30,765 \text {. }\end{array}$ \\
\hline & & & & & $\begin{array}{l}\text { Cases in } 44 \text { regions outside } \\
\text { of Wuhan by Feb } 27\end{array}$ & $\begin{array}{l}\text { Travel measures implemented three days } \\
\text { earlier }\end{array}$ & $\begin{array}{l}\text { Further reduce the number of cases to between } \\
15,768-21,245 \text {. }\end{array}$ \\
\hline Su et al. (2020) & Modelled & Deterministic SEIR model & $\begin{array}{l}\mathrm{R} 0=2.91,2.78,2.02 \text {, and } 1.75 \text { for } \\
\text { Beijing, Shanghai, Guangzhou, and } \\
\text { Shenzhen respectively }\end{array}$ & $\begin{array}{l}\text { Wuhan travel measures in } \\
\text { combination with other non- } \\
\text { pharmaceutical interventions }\end{array}$ & $\begin{array}{l}\text { Transmission rates in four } \\
\text { metropolitan areas of China }\end{array}$ & $\begin{array}{l}\text { Different contract rates were assumed to } \\
\text { result from reduced population flow. }\end{array}$ & $\begin{array}{l}\text { Travel restrictions contributed to a reduction in } \\
\text { the contact rate and reduced the time to peak and } \\
\text { the number of cases. }\end{array}$ \\
\hline Jiang et al. (2020) & Modelled & $\begin{array}{l}\text { Time-varying sparse vector } \\
\text { autoregressive model }\end{array}$ & Incubation period: 10 days & $\begin{array}{l}\text { Travel measures introduced in } \\
5 \text { cities of Hubei (Wuhan, } \\
\text { Huanggang, Ezhou, Chibi and } \\
\text { Zhijijang) }\end{array}$ & $\begin{array}{l}\text { Daily transmission routes } \\
\text { from Hubei to other } \\
\text { provinces through Feb } 19\end{array}$ & $\begin{array}{l}\text { Travel measures started to be implemented } \\
\text { on Jan } 23\end{array}$ & $\begin{array}{l}\text { Travel restrictions reduced transmission between } \\
\text { provinces }\end{array}$ \\
\hline \multirow[t]{3}{*}{ Lai et al. (2020) } & \multirow[t]{3}{*}{ Modelled } & \multirow[t]{3}{*}{ Stochastic SEIR model } & \multirow[t]{3}{*}{$\mathrm{R} 0: 2.2$; incubation period: 5.2 days } & \multirow[t]{3}{*}{$\begin{array}{l}\text { Wuhan travel measures in } \\
\text { combination with other non- } \\
\text { pharmaceutical interventions }\end{array}$} & $\begin{array}{l}\text { Cases in Mainland China } \\
\text { outside of Wuhan }\end{array}$ & Travel measures implemented on Jan 23 & $\begin{array}{l}\text { Early detection and isolation of cases more } \\
\text { effective than travel restrictions; travel restricts } \\
\text { reduced the number of cases outide of Wuhan as } \\
\text { well as its geographic spread. }\end{array}$ \\
\hline & & & & & $\begin{array}{l}\text { Cases in Mainland China } \\
\text { outside of Wuhan }\end{array}$ & $\begin{array}{l}\text { If travel restrictions of same magnitude } \\
\text { were implemented one, two, or three } \\
\text { weeks earlier }\end{array}$ & $\begin{array}{l}\text { If interventions were conducted one, two, or } \\
\text { three weeks earlier, cases will reduce by } 66 \% \text {, } \\
86 \% \text {, or } 95 \% \text { respectively. }\end{array}$ \\
\hline & & & & & $\begin{array}{l}\text { Total number of cases } \\
\text { outside of Wuhan }\end{array}$ & $\begin{array}{l}\text { If travel restrictions of same magnitude } \\
\text { were implemented one, two, or three } \\
\text { weeks later. }\end{array}$ & $\begin{array}{l}\text { If interventions were conducted one, two, or } \\
\text { three weeks later, cases may increase 3-fold, 7- } \\
\text { fold, or } 18 \text {-fold respectively }\end{array}$ \\
\hline $\begin{array}{l}\text { Hossain et al. } \\
(2020)\end{array}$ & Modelled & Meta-population model & $\begin{array}{l}\text { R0: } 2.92 ; \text { latent period: } 5.2 \text { days; } \\
\text { generation time: } 8.4 \text { days }\end{array}$ & Border control and quarantine & $\begin{array}{l}\text { Arrival time outside of } \\
\text { Wuhan }\end{array}$ & Theoretical application of measures & $\begin{array}{l}\text { Arrival time is delayed by } 32.5 \text { days and } 44 \text { days } \\
\text { under a low R } 0(1.4) \text { but under higher } \mathrm{R} 0(2.92) \\
\text { only } 10 \text { extra days can be gained. }\end{array}$ \\
\hline
\end{tabular}




\begin{tabular}{|c|c|c|c|c|c|c|c|c|}
\hline $\begin{array}{l}\text { Anthors } \\
\end{array}$ & $\begin{array}{l}\text { Clear and precise definition of } \\
\text { research question }\end{array}$ & $\begin{array}{l}\text { Travel restriction measures included in } \\
\text { analysis }\end{array}$ & Outcomes & $\begin{array}{l}\begin{array}{l}\text { Suitable mathematical } \\
\text { modelling }\end{array} \\
\end{array}$ & Major model assumptions described & Other related factors adjusted & Model validated & Uncertainty analysis \\
\hline 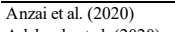 & 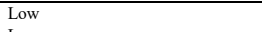 & Low & Low & Low & Low & Moderate & High & High \\
\hline $\begin{array}{l}\text { Adekunle et al. (2020) } \\
\text { Adiga et al. (2020) }\end{array}$ & Low & Low & Low & Moderate & Low & Moderate & Low & Low \\
\hline $\begin{array}{l}\text { Adga a tal. (2020) } \\
\text { Aleta et al (2020) }\end{array}$ & $\begin{array}{l}\text { Low } \\
\text { Low }\end{array}$ & $\begin{array}{l}\text { Modrate } \\
\text { Low }\end{array}$ & $\begin{array}{l}\text { Low } \\
\text { Low }\end{array}$ & $\begin{array}{l}\text { Low } \\
\text { Moderate }\end{array}$ & $\begin{array}{l}\text { Low } \\
\text { Low }\end{array}$ & $\begin{array}{l}\text { High } \\
\text { High }\end{array}$ & $\begin{array}{l}\text { Low } \\
\text { Low }\end{array}$ & $\begin{array}{l}\text { High } \\
\text { Low }\end{array}$ \\
\hline $\begin{array}{l}\text { Alete a tal. (2020) } \\
\text { Boldog et al. (2020) }\end{array}$ & $\begin{array}{l}\text { Low } \\
\text { Low }\end{array}$ & $\begin{array}{l}\text { Low } \\
\text { Low }\end{array}$ & $\begin{array}{l}\text { Low } \\
\text { Low }\end{array}$ & $\begin{array}{l}\text { Moderate } \\
\text { Low }\end{array}$ & $\begin{array}{l}\text { Low } \\
\text { Low }\end{array}$ & $\begin{array}{l}\text { Hign } \\
\text { Moderate }\end{array}$ & $\begin{array}{l}\text { Low } \\
\text { High }\end{array}$ & $\begin{array}{l}\text { Low } \\
\text { Low }\end{array}$ \\
\hline $\begin{array}{l}\text { Chinazi i tal. (2020) } \\
\text { C. }\end{array}$ & Low & Low & Low & $\begin{array}{l}\text { Low } \\
\text { Low }\end{array}$ & Low & Low & Low & Low \\
\hline Clifford et al. (2020) & Low & Low & Low & Low & Low & High & High & Low \\
\hline Costantino et al. (2020) & Low & Low & Low & Low & Low & Moderate & High & Moderate \\
\hline Cowling et al. (2020) & Low & High & Low & Low & $\mathrm{NA}$ & High & $\mathrm{NA}$ & $\mathrm{NA}$ \\
\hline Fang et al. (2020) & Low & Moderate & Low & Low & Low & Low & Low & Low \\
\hline $\begin{array}{l}\text { Hossain te al. (2020) } \\
\text { Hou et al. }(2020)\end{array}$ & $\begin{array}{l}\text { Low } \\
\text { Low }\end{array}$ & $\begin{array}{l}\text { Low } \\
\text { High }\end{array}$ & $\begin{array}{l}\text { Low } \\
\text { Low }\end{array}$ & $\begin{array}{l}\text { Low } \\
\text { Low }\end{array}$ & $\begin{array}{l}\text { Low } \\
\text { Low }\end{array}$ & $\begin{array}{l}\text { Moderate } \\
\text { High }\end{array}$ & Low & High \\
\hline $\begin{array}{l}\text { Hou et at. (2020) } \\
\text { Jiang et al. (22020) }\end{array}$ & $\begin{array}{l}\text { Low } \\
\text { Low }\end{array}$ & 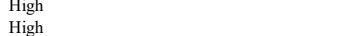 & $\begin{array}{l}\text { Low } \\
\text { Low }\end{array}$ & $\begin{array}{l}\text { Low } \\
\text { Low }\end{array}$ & $\begin{array}{l}\text { Low } \\
\text { Low }\end{array}$ & $\begin{array}{l}\text { High } \\
\text { High }\end{array}$ & $\begin{array}{l}\text { Low } \\
\text { Low }\end{array}$ & Low \\
\hline $\begin{array}{l}\text { Klausner et al (2020) } \\
\text { Kal }\end{array}$ & $\begin{array}{l}\text { Low } \\
\text { Low }\end{array}$ & $\begin{array}{l}\text { High } \\
\text { High }\end{array}$ & $\begin{array}{l}\text { Low } \\
\text { High }\end{array}$ & $\begin{array}{l}\text { Low } \\
\text { High }\end{array}$ & $\begin{array}{l}\text { Low } \\
\text { High }\end{array}$ & $\begin{array}{l}\text { High } \\
\text { High }\end{array}$ & $\begin{array}{l}\text { Low } \\
\text { High }\end{array}$ & High \\
\hline Kraemer et al. (2020) & Low & Low & Low & Low & $\begin{array}{l}\text { Low } \\
\text { Low }\end{array}$ & Low & $\begin{array}{l}\text { Low } \\
\text { Low }\end{array}$ & $\begin{array}{l}\text { Low } \\
\text { Low }\end{array}$ \\
\hline Kucharski et al. (2020) & Low & High & Low & Low & Low & High & Low & Low \\
\hline Lai et al. (2020) & Low & Low & Low & Low & Low & Low & Low & Low \\
\hline Lau et al. (2020) & Low & Moderate & Low & Low & Low & High & $\mathrm{NA}$ & $\mathrm{NA}$ \\
\hline $\begin{array}{l}\text { Li i tal. (2020) } \\
\text { Linka tal. (2020) }\end{array}$ & Low & High & Low & Low & Low & High & Low & Low \\
\hline $\begin{array}{l}\text { Linka e tal. (2020) } \\
\text { Liu et al (2020) }\end{array}$ & $\begin{array}{l}\text { Low } \\
\text { Low }\end{array}$ & $\begin{array}{l}\text { Low } \\
\text { High }\end{array}$ & $\begin{array}{l}\text { Low } \\
\text { Low }\end{array}$ & $\begin{array}{l}\text { Low } \\
\text { Low }\end{array}$ & $\begin{array}{l}\text { Low } \\
\text { Low }\end{array}$ & $\begin{array}{l}\text { High } \\
\text { High }\end{array}$ & High & Low \\
\hline $\begin{array}{l}\text { Lue etal. (2020) } \\
\text { Mandal et al. (2020) }\end{array}$ & $\begin{array}{l}\text { Low } \\
\text { Low }\end{array}$ & $\begin{array}{l}\begin{array}{l}\text { High } \\
\text { Low }\end{array} \\
\text { ing }\end{array}$ & $\begin{array}{l}\text { Low } \\
\text { Low }\end{array}$ & $\begin{array}{l}\text { Low } \\
\text { Low }\end{array}$ & $\begin{array}{l}\text { Low } \\
\text { Low }\end{array}$ & $\begin{array}{l}\text { High } \\
\text { Moderate }\end{array}$ & $\begin{array}{l}\text { Low } \\
\text { High }\end{array}$ & $\begin{array}{l}\text { Low } \\
\text { Low }\end{array}$ \\
\hline $\begin{array}{l}\text { Mandal et al. (2020) } \\
\text { Shi et al. (2020) }\end{array}$ & $\begin{array}{l}\text { Low } \\
\text { Low }\end{array}$ & $\begin{array}{l}\text { Low } \\
\text { High }\end{array}$ & $\begin{array}{l}\text { Low } \\
\text { Low }\end{array}$ & $\begin{array}{l}\text { Low } \\
\text { Low }\end{array}$ & $\begin{array}{l}\text { Low } \\
\text { Low }\end{array}$ & $\begin{array}{l}\text { Moderate } \\
\text { High }\end{array}$ & $\begin{array}{l}\text { Iigh } \\
\text { Low }\end{array}$ & $\begin{array}{l}\text { Low } \\
\text { Low }\end{array}$ \\
\hline Su et al. (2020) & Low & High & Low & Low & Low & High & Low & High \\
\hline Tang et al. (2020) & Low & Low & Low & Low & Low & High & Low & Low \\
\hline Tian et al. (2020) & Low & Low & Low & Low & Low & Low & Low & Low \\
\hline Wells et al. (2020) & Low & Low & Low & Low & Low & Low & Low & Low \\
\hline Wu et al. (2020) & Low & Low & Low & Low & Low & $\begin{array}{l}\text { Moderate } \\
\text { High }\end{array}$ & Low & Low \\
\hline
\end{tabular}

Notes:
Domains of risk of bias: low means the author had adequately addressed the domain; moderate represents that the domain was addressed spartial or incomplemently; high means the domain was poorly addressed.
NA: Not applicable. 


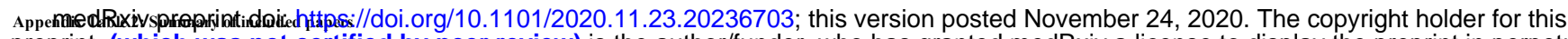

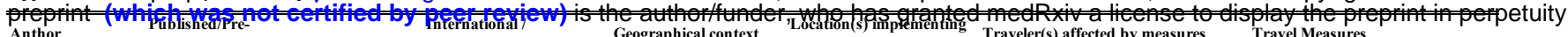

\begin{tabular}{|c|c|c|c|c|c|c|c|}
\hline & printed & & Interprovinclal & & & & \\
\hline$\overline{\text { Anzai et al. (2020) }}$ & Published & Modelled & tunisnatade a & teidbnder a c & 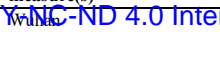 & 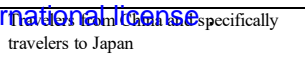 & Suspended air transportation \\
\hline $\begin{array}{l}\text { Adekunle et al. } \\
(2020)\end{array}$ & Published & Modelled & International & Australia & Australia & $\begin{array}{l}\text { Travelers from China, Iran, Italy, and } \\
\text { South Korea to Australia }\end{array}$ & $\begin{array}{l}\text { Suspended air transportation; } \\
\text { Provincial border closure }\end{array}$ \\
\hline Adiga et al. (2020) & Pre-printed & Modelled & International & Global & Airlines in 24 countries & Outbound travelers from China & Suspended air transportation \\
\hline Aleta et al. (2020) & Published & Modelled & Interprovincial & Mainland China & Wuhan & Travelers within Mainland China & $\begin{array}{l}\text { Suspended land, air, sea } \\
\text { transportation; Provincial border } \\
\text { closure }\end{array}$ \\
\hline Boldog et al. (2020) & Published & Modelled & International & Global & Wuhan and other countries & Outbound travelers from China & $\begin{array}{l}\text { Suspended land, air, sea } \\
\text { transportation; Entry screening }\end{array}$ \\
\hline $\begin{array}{l}\text { Chinazzi et al. } \\
(2020)\end{array}$ & Published & Modelled & Both & Global & Wuhan and other countries & Outbound travelers from China & $\begin{array}{l}\text { Suspended air transportation; } \\
\text { Provincial border closure }\end{array}$ \\
\hline Clifford et al. (2020) & Published & Modelled & International & Global & Destination countries & Inbound travelers & Entry and exit screening \\
\hline $\begin{array}{l}\text { Costantino et al. } \\
(2020)\end{array}$ & Published & Modelled & International & Australia & Australia & Travellers from China to Australia & Suspended air transportation \\
\hline $\begin{array}{l}\text { Cowling et al. } \\
(2020)\end{array}$ & Published & Observational & International* & Hong Kong SAR & Hong Kong SAR & Inbound travelers & $\begin{array}{l}\text { Suspended land, air, sea } \\
\text { transportation; Entry screening; Entry } \\
\text { quarantine }\end{array}$ \\
\hline Fang et al. (2020) & Published & Modelled & Interprovincial & Mainland China & Wuhan & $\begin{array}{l}\text { Travelers to } 363 \text { cities in China from } \\
\text { Wuhan }\end{array}$ & Provincial border closure \\
\hline $\begin{array}{l}\text { Hossain et al. } \\
(2020)\end{array}$ & Published & Modelled & Interprovincial & Mainland China & Wuhan & $\begin{array}{l}\text { Travelers to major cities in China from } \\
\text { Wuhan }\end{array}$ & $\begin{array}{l}\text { Provincial border closure; Entry } \\
\text { quarantine }\end{array}$ \\
\hline Hou et al. (2020) & Pre-printed & Modelled & Interprovincial & Mainland China & Wuhan & Travelers within Mainland China & $\begin{array}{l}\text { Suspended land, air, sea } \\
\text { transportation; Provincial border } \\
\text { closure }\end{array}$ \\
\hline Jiang et al. (2020) & Published & Modelled & Interprovincial & Mainland China & Wuhan & Travelers within Mainland China & $\begin{array}{l}\text { Suspended land, air, sea } \\
\text { transportation; Provincial border } \\
\text { closure }\end{array}$ \\
\hline $\begin{array}{l}\text { Klausner et al. } \\
(2020)\end{array}$ & Pre-printed & Modelled & International & Israel & Israel & $\begin{array}{l}\text { Inbound travelers, especially those from } \\
\text { China }\end{array}$ & Entry quarantine \\
\hline $\begin{array}{l}\text { Kraemer et al. } \\
(2020)\end{array}$ & Published & Modelled & Interprovincial & Mainland China & Hubei and other provinces & Travelers within Mainland China & $\begin{array}{l}\text { Suspended land, air, sea } \\
\text { transportation; Provincial border } \\
\text { closure }\end{array}$ \\
\hline $\begin{array}{l}\text { Kucharski et al. } \\
(2020)\end{array}$ & Published & Modelled & International & Mainland China & Wuhan & $\begin{array}{l}\text { Outbound international travelers from } \\
\text { Wuhan }\end{array}$ & $\begin{array}{l}\text { Suspended land, air, sea } \\
\text { transportation; Provincial border } \\
\text { closure }\end{array}$ \\
\hline Lai et al. (2020) & Published & Modelled & Interprovincial & Mainland China & $\begin{array}{l}\text { Wuhan and other cities } \\
\text { within China }\end{array}$ & Travelers within Mainland China & $\begin{array}{l}\text { Suspended land, air, sea } \\
\text { transportation; Provincial border } \\
\text { closure }\end{array}$ \\
\hline Lau et al. (2020) & Published & Observational & Interprovincial & Mainland China & Wuhan & Travelers within Mainland China & $\begin{array}{l}\text { Suspended land, air, sea } \\
\text { transportation; Provincial border } \\
\text { closure }\end{array}$ \\
\hline Li et al. (2020) & Published & Modelled & Interprovincial & Mainland China & Wuhan & Travelers within Mainland China & $\begin{array}{l}\text { Suspended land, air, sea } \\
\text { transportation; Provincial border } \\
\text { closure }\end{array}$ \\
\hline Linka et al. (2020) & Published & Modelled & International & Europe & $\begin{array}{l}\text { European Union member } \\
\text { countries }\end{array}$ & Travelers within the European Union & $\begin{array}{l}\text { Suspended land, air, sea } \\
\text { transportation; National border } \\
\text { closure }\end{array}$ \\
\hline Liu et al. (2020) & Published & Observational & Interprovincial & Mainland China & Wuhan & Travelers within Mainland China & $\begin{array}{l}\text { Suspended land, air, sea } \\
\text { transportation; National border } \\
\text { closure }\end{array}$ \\
\hline Mandal et al. (2020) & Published & Modelled & International & India & India & Inbound travelers to India & Entry screening \\
\hline Shi et al. (2020) & Pre-printed & Modelled & Interprovincial & Mainland China & Wuhan & Travelers within Mainland China & $\begin{array}{l}\text { Suspended land, air, sea } \\
\text { transportation; Provincial border } \\
\text { closure }\end{array}$ \\
\hline Su et al. (2020) & Published & Modelled & Interprovincial & Mainland China & Provinces within China & Travelers within Mainland China & $\begin{array}{l}\text { Suspended land, air, sea } \\
\text { transportation; Provincial border } \\
\text { closure }\end{array}$ \\
\hline Tang et al. (2020) & Published & Modelled & Interprovincial & Mainland China & Wuhan & Travelers within Mainland China & $\begin{array}{l}\text { Suspended land, air, sea } \\
\text { transportation; Provincial border } \\
\text { closure }\end{array}$ \\
\hline Tian et al. (2020) & Published & Modelled & Interprovincial & Mainland China & Wuhan & Travelers within Mainland China & $\begin{array}{l}\text { Suspended air transportation; } \\
\text { Provincial border closure }\end{array}$ \\
\hline Wells et al. (2020) & Published & Modelled & International & Global & Wuhan & $\begin{array}{l}\text { Inbound international travelers from } \\
\text { China }\end{array}$ & $\begin{array}{l}\text { Suspended air transportation; } \\
\text { Provincial border closure; Entry } \\
\text { Screening; Entry Quarantine }\end{array}$ \\
\hline Wu et al. (2020) & Published & Modelled & Interprovincial & Mainland China & Wuhan and Hubei province & Travelers within Mainland China & $\begin{array}{l}\text { Suspended land, air, sea } \\
\text { transportation; Provincial border } \\
\text { closure }\end{array}$ \\
\hline Yuan et al. (2020) & Pre-printed & Modelled & Interprovincial & Mainland China & Wuhan & Travelers within Mainland China & $\begin{array}{l}\text { Suspended land, air, sea } \\
\text { transportation; Provincial border } \\
\text { closure }\end{array}$ \\
\hline
\end{tabular}

